Appendix A: List of initiatives underpinning the different discourses

\begin{tabular}{|c|c|c|}
\hline Discourse & Initiative & Description \\
\hline \multirow[t]{3}{*}{$\begin{array}{l}\text { Open source inputs } \\
\text { in agricultura }\end{array}$} & Opensourceseeds & $\begin{array}{l}\text { The Open Source Seed Initiative was founded in } 2012 \text { by a group of plant breeders, farmers and seed } \\
\text { companies (Adaptive Seeds, 2020) and it is organized by internal rules based on mutual trust. In Germany, } \\
\text { the initiative was implemented through the service provider OpenSourceSeeds (2018) in } 2017 \text {. }\end{array}$ \\
\hline & Save our seeds & $\begin{array}{l}\text { This initiative promotes the cultivation of new plant types and animal races for organic agriculture } \\
\text { (Zukunftsstiftung Landwirtschaft, 2002) working together with breeders that develop their own varieties } \\
\text { adapted to growing without pesticides or mineral fertilizer. }\end{array}$ \\
\hline & Community seed banks & $\begin{array}{l}\text { In Europe they are mostly based on seed savers', gardeners' and farmers' networks, that maintain and } \\
\text { develop agricultural biodiversity, enhance access to seeds and plants adapted to local conditions, provide } \\
\text { training and awareness activities, contributing to sustainable agriculture and food sovereignty (Verein zum } \\
\text { Erhalt der Nutzpflanzen Vielfalt e.V., 2019) }\end{array}$ \\
\hline \multirow[t]{2}{*}{$\begin{array}{l}\text { Joint responsibility } \\
\text { for food products }\end{array}$} & $\begin{array}{l}\text { Community supported } \\
\text { agriculture }\end{array}$ & $\begin{array}{l}\text { Is a system that closely connects producers and consumers by allowing the latter ones to subscribe to the } \\
\text { harvest of a certain farm or group of farms, so that they provide the growers with working capital and share } \\
\text { with them the risks and benefits of farming (Cone \& Myhre, 2000; DeMuth, 1993). }\end{array}$ \\
\hline & Slow Food & $\begin{array}{l}\text { Slow Food is a global, grassroots organization working on preventing the disappearance of local food } \\
\text { cultures and traditions, and counteract the rise of fast food and industrial food production (Slow Food } \\
\text { Deutschland e.V., 2019). Slow Food coined the term "co-producers" for consumers: They take joint } \\
\text { responsibility in the food chain as their choices influence the way food is produced and distributed. }\end{array}$ \\
\hline
\end{tabular}




\begin{tabular}{|c|c|c|}
\hline$\underline{\text { Discourse }}$ & Initiative & $\underline{\text { Description }}$ \\
\hline \multirow[t]{3}{*}{$\begin{array}{l}\text { Reducing food } \\
\text { waste }\end{array}$} & $\begin{array}{l}\text { Teller statt Tonne (Plate } \\
\text { instead of bin ) }\end{array}$ & $\begin{array}{l}\text { From } 2012 \text { to } 2015 \text {, this was an educational program from Slow Food Germany in cooperation with the } \\
\text { Ministry of Cooperation (BMZ) to raise awareness of food waste among children and young people and } \\
\text { analyze the causes of waste. The project questioned the appropriate role of a functioning market and how } \\
\text { regional and seasonal consumption could help reduce food waste (Slow Food Deutschland gUG, 2015). }\end{array}$ \\
\hline & $\begin{array}{l}\text { Leere Tonne Kampagne } \\
\text { (Empty Bin Campaign) }\end{array}$ & $\begin{array}{l}\text { Launched by some NGOs in Germany, this project aimed to prohibit the disposal of still-edible food from } \\
\text { supermarkets or other companies (Foodsharing e.V., 2017). Other EU countries already take legal action } \\
\text { against food waste, to prevent leftover supermarket food from being carted away as garbage. }\end{array}$ \\
\hline & Foodsharing & $\begin{array}{l}\text { This effort was created in Berlin (Germany) in } 2012 \text { as an educational and political initiative to work } \\
\text { against food waste by rescuing overproduced food for private households and companies (Foodsharing } \\
\text { e.V., 2012). The foodsharing community is organized through an online platform and it is carried out by a } \\
\text { volunteer network - food sharers and savers (Foodsharing e.V., 2012). }\end{array}$ \\
\hline \multirow[t]{3}{*}{$\begin{array}{l}\text { Safeguarding food } \\
\text { culture and } \\
\text { knowledge }\end{array}$} & Ark of taste & $\begin{array}{l}\text { It is one of the most important initiatives of Slow Food. It is an online catalog that gathers alerts from } \\
\text { people who have seen the specialties of their communities disappear and miss the sense of identity } \\
\text { expressed through their food, and who see this as a loss of their culture and history. The worldwide } \\
\text { inventory includes thousands of products including old varieties of plants and livestock and traditional } \\
\text { handcrafts and recipes (Slow Food Foundation, 2017). }\end{array}$ \\
\hline & $\begin{array}{l}\text { UNESCO ICH Initiatives } \\
\text { on food }\end{array}$ & $\begin{array}{l}\text { This UNESCO's initiative aims at protecting the wealth of knowledge on oral traditions, performing arts, } \\
\text { social practices, rituals, festive events, knowledge and practices concerning nature, traditional crafts, } \\
\text { traditions or living expressions inherited from the past generations (UNESCO, 2012). Among the } \\
\text { Intangibles accepted in the UNESCO list is knowledge related to food. }\end{array}$ \\
\hline & The houshold license & $\begin{array}{l}\text { The German Association of Rural Women (Deutscher Landfrauenverband e.V., 2020) is nationwide the } \\
\text { largest organization for women who live in the countryside. It aims to improve their quality of life, } \\
\text { working conditions and socio-political participation in rural areas (Deutscher Landfrauenverband e.V., } \\
\text { 2020). The household license is an educational initiative in schools from the German Association of Rural } \\
\text { Women in the region of Württemberg-Hohenzollern, supported by regional governments. The project helps } \\
\text { students to acquire skills in the areas of health, nutrition, food preparation and household management. } \\
\text { Therewith it particularly aims at preserving cultural knowledge of food processing and preparation. }\end{array}$ \\
\hline
\end{tabular}




\section{Bibliography Appendix A}

Adaptive Seeds. (2020). Bringing biodiversity back. Retrieved from https://www.adaptiveseeds.com/

Cone, C., \& Myhre, A. (2000). Community-Supported Agriculture: A Sustainable Alternative to Industrial Agriculture? Human Organization, 59, $187-197$. doi:10.17730/humo.59.2.715203t206g2j153

DeMuth, S. (1993). Community Supported Agriculture (CSA): An annotated bibliography and resource guide. Beltsville, Md.: National Agricultural Library.

Deutscher Landfrauenverband e.V. (2020). Land Frauen. Retrieved from https://www.landfrauen.info/verband/

Foodsharing e.V. (2012). foodsharing. Retrieved from https://foodsharing.de/

Foodsharing e.V. (2017). Leere Tonne Kampagne. Retrieved from https://foodsharing.de/leeretonne

Hall, P. A. (1993). Policy Paradigms, Social Learning and the State: The Case of Economic Policy-Making in Britain. Comparative Politics, 25(3), 275-296.

Marktschwärmer Germany. (2014). Fairer einkaufen. Besser essen. Retrieved from https://wirsind.marktschwaermer.de/

OpenSourceSeeds - AGRECOL. (2018). Open Source Seeds. Retrieved from https://opensourceseeds.org/

Slow Food Deutschland e.V. (2019). Slow Food Deutschland. Retrieved from https://www.slowfood.de/

Slow Food Deutschland gUG. (2015). Teller Statt Tonne. Retrieved from http://www.teller-statt-tonne.de

Slow Food Foundation. (2017). Ark of taste. Retrieved from https://www.fondazioneslowfood.com/en/what-we-do/the-ark-of-taste/

United Nations Educational Scientific and Cultural Organization. (2012). Intangible Cultural Heritage Retrieved from https://ich.unesco.org/

Verein zum Erhalt der Nutzpflanzen Vielfalt e.V. (2019). Nutzpflanzen Vielfalt - Saatgut ist Kulturgut. Retrieved from https://www.nutzpflanzenvielfalt.de

Zukunftsstiftung Landwirtschaft. (2002). Save Our Seeds. Retrieved from https://www.saveourseeds.org/ 
Appendix B: Classification Food-as-a Commons Initiatives according to level of policy transformation achieved.

\begin{tabular}{|c|c|c|c|c|}
\hline$\underline{\text { Initiative }}$ & $\frac{\text { Stages in the policy cycle }}{\text { (Lasswell, 1927) }^{1}}$ & $\frac{\frac{\text { Streams in a policy }}{\text { process (Kingdon, }}}{1994)}$ & $\begin{array}{c}\text { Level of } \\
\frac{\text { institutionalization }}{\text { (Lynggaard, 2007) }}\end{array}$ & $\begin{array}{l}\text { Different orders of policy } \\
\text { change }(\text { Hall, 1993) }\end{array}$ \\
\hline Opensourceseeds & Agenda-setting (still in niches) & Problem/Policies & Articulation & No policy change yet \\
\hline Save our seeds & Agenda-setting (still in niches) & Problem/Policies & Articulation & No policy change yet \\
\hline Community seed banks & Agenda-setting (still in niches) & Problem/Policies & Articulation & No policy change yet \\
\hline Community supported agriculture & Agenda-setting (still in niches) & Problem/Policies & Articulation & No policy change yet \\
\hline Slow Food & Agenda-setting & Problem/Policies & Articulation & No policy change yet \\
\hline Market Enthusiasts & Agenda-setting & Problem/Policies & Articulation & No policy change yet \\
\hline Plate instead of bin & Agenda-setting & Problem/Policies & Institutionalization & First order policy change \\
\hline Empty Bin Campaign & $\begin{array}{l}\text { Agenda-setting/policy } \\
\text { formulation }\end{array}$ & Problem/Policies & Institutionalization & First order policy change \\
\hline Foodsharing & Agenda-setting & Problem/Policies & Institutionalization & First order policy change \\
\hline Ark of taste & Agenda-setting & Problem/Policies & Articulation & No policy change yet \\
\hline UNESCO ICH Initiatives on food & Problem definition & Problem & Articulation & No policy change yet \\
\hline The houshold license & Agenda-setting (still in niches) & Problem/Policies & Articulation & No policy change yet \\
\hline
\end{tabular}


Appendix C. List of Documents

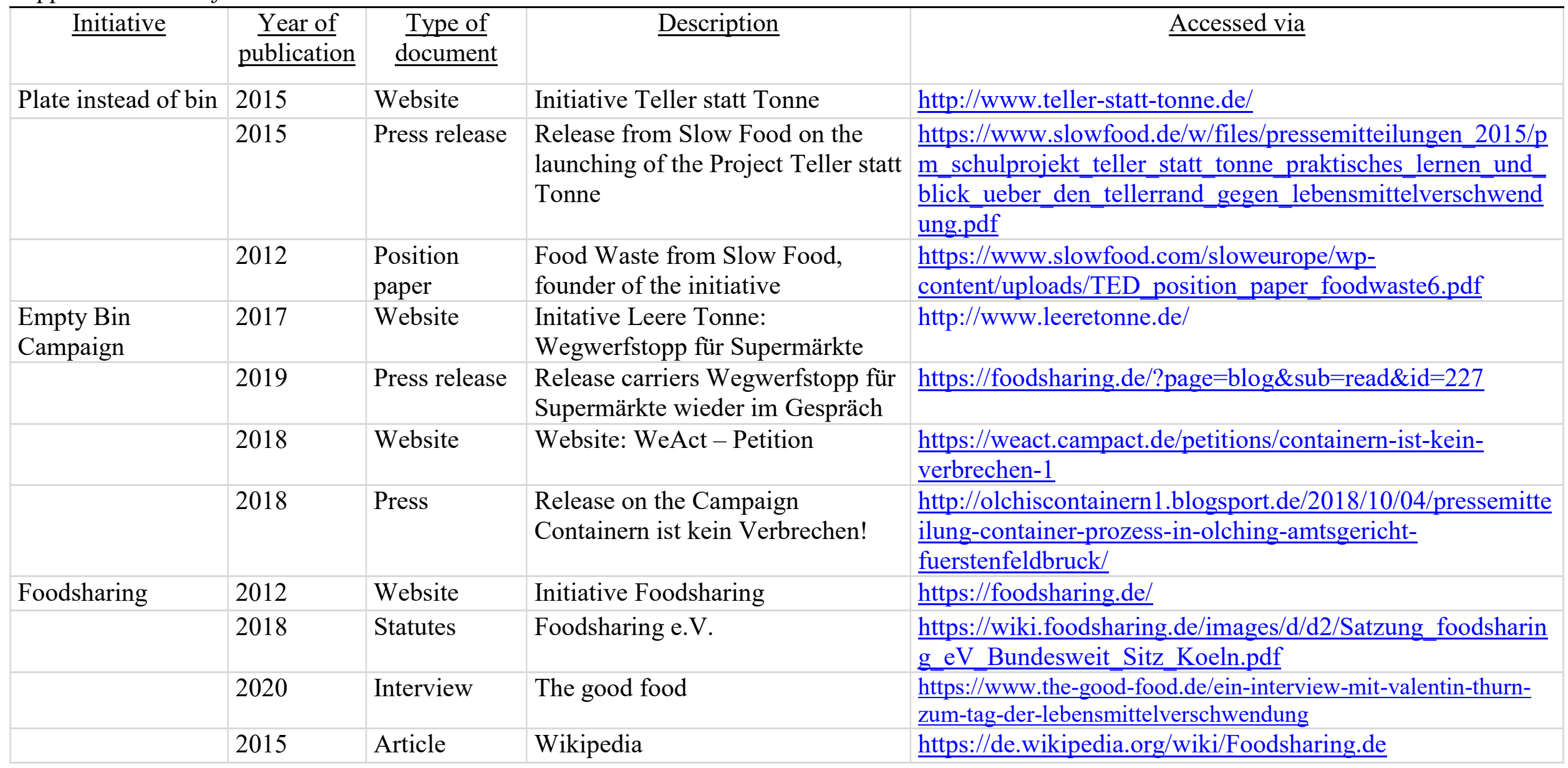


Appendix C. List of Documents

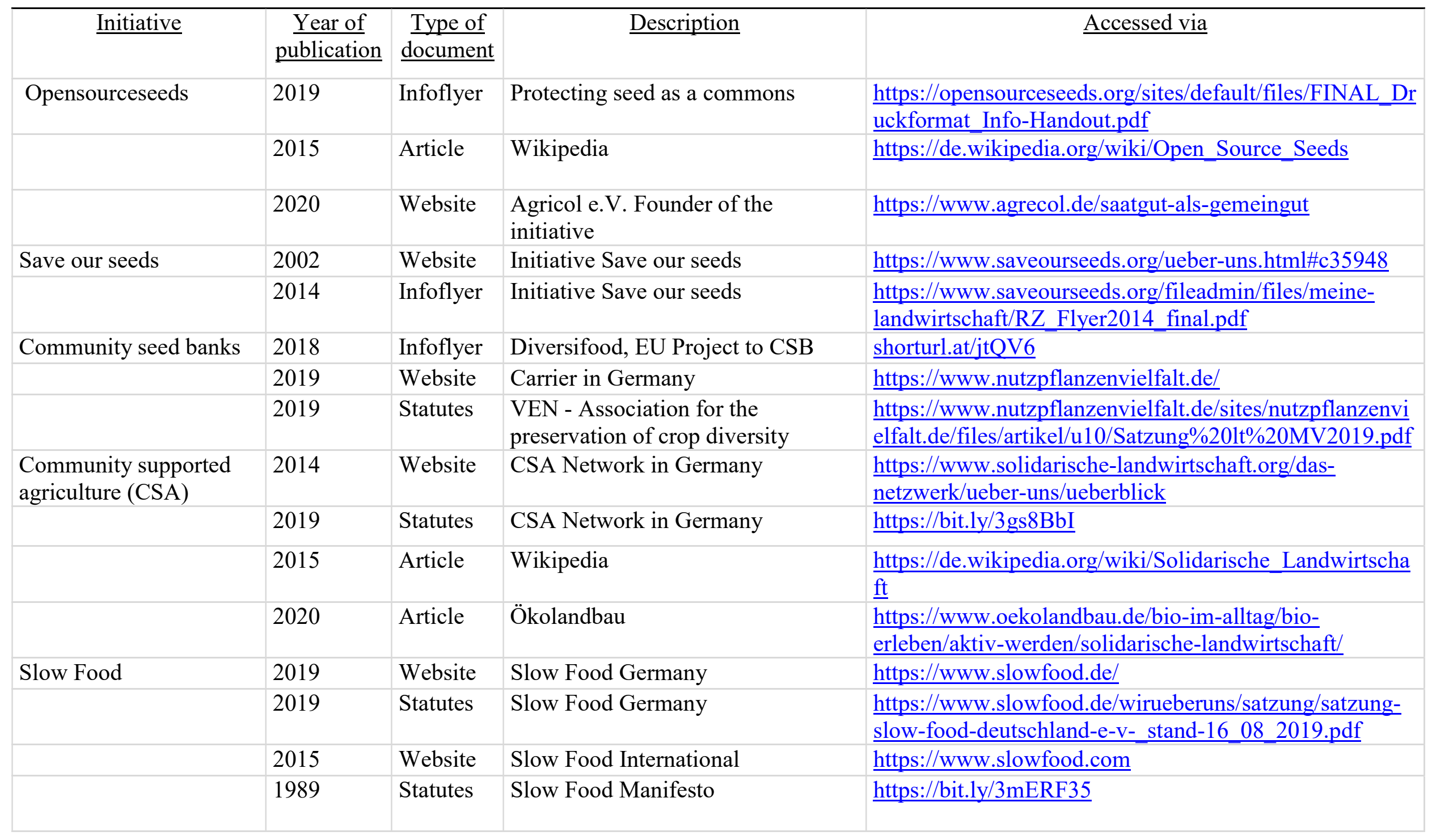


Appendix C. List of Documents

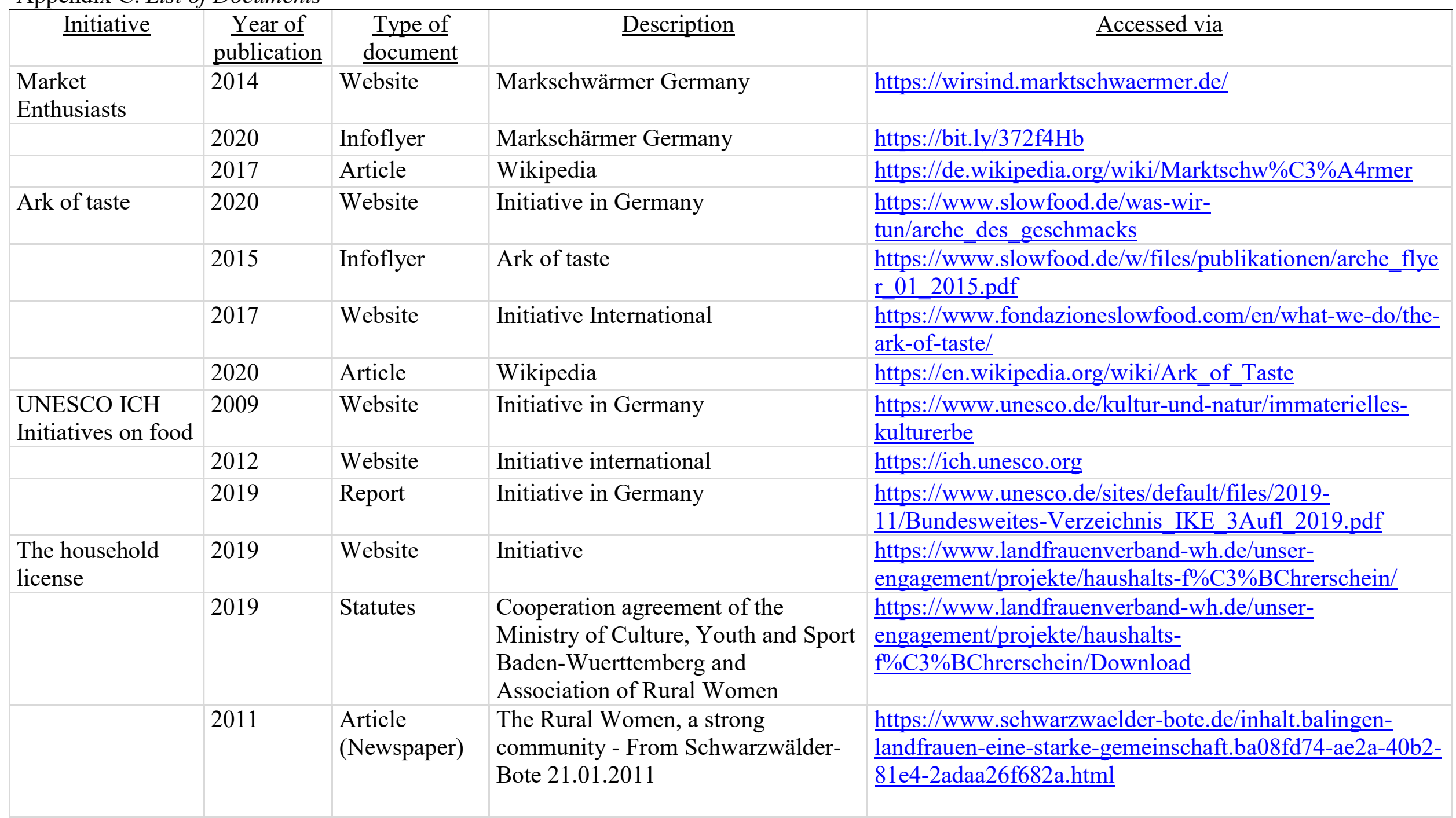


